\title{
TEGDMA and UDMA monomers released from composite dental material polymerized with diode and halogen lamps
}

\author{
Agnieszka Wacławczyk ${ }^{1, A-D}$, Lidia Postek-Stefańska ${ }^{1, A, E, F}$, Daria Pietraszewska, ${ }^{1, B, C, E}$, \\ Ewa Birkner ${ }^{2, A, E, F}$, Jolanta Zalejska-Fiolka ${ }^{2, A, C, E, F}$, Iwona Wysoczańska-Jankowicz ${ }^{1, C, E}$ \\ ${ }^{1}$ Department of Pediatric Dentistry, School of Medicine with the Division of Dentistry in Zabrze, Medical University of Silesia in Katowice, Poland \\ ${ }^{2}$ Department of Biochemistry, School of Medicine with the Division of Dentistry in Zabrze, Medical University of Silesia in Katowice, Poland \\ A - research concept and design; $\mathrm{B}$ - collection and/or assembly of data; $\mathrm{C}$ - data analysis and interpretation; \\ $D$ - writing the article; $E$ - critical revision of the article; $F$ - final approval of the article
}

Address for correspondence

Agnieszka Wacławczyk

E-mail: marcinekaga1976@gmail.com

Funding sources

The investigation was supported by statutory activities of Medical University of Silesia.

Conflict of interest

None declared

Received on June 8, 2016

Reviewed on September 16, 2016

Accepted on January 10, 2017

DOI

$10.17219 /$ acem $/ 68382$

Copyright

Copyright by Author(s)

This is an article distributed under the terms of the

Creative Commons Attribution Non-Commercial License

(http://creativecommons.org/licenses/by-nc-nd/4.0/)

\begin{abstract}
Background. More than 35 substances released from composite fillings have been identified. Among these, basic monomers and the so-called co-monomers are most often reported. The substances released from polymer-based materials demonstrate allergenic, cytotoxic, genotoxic, mutagenic, embryotoxic, teratogenic, and estrogenic properties.
\end{abstract}

Objectives. The aim of this study was to measure the amounts of triethylene glycol dimethacrylate (TEGDMA) and urethane dimethacrylate (UDMA) monomers released from composite dental fillings to citrate-phosphate buffer with the pH of 4, 6, 8 after $24 \mathrm{~h}$ and 6 months from the polymerization.

Material and methods. Ten samples for each polymerization method had been made from the composite material (Filtek Supreme XT, 3M ESPE, St. Paul, USA), which underwent polymerization using the following lamps: halogen lamp (Translux CL, Heraeus Kulzer, Hanau, Germany) (sample H) and diode lamp (Elipar Freelight 2, 3M ESPE), with soft start function (group DS) and without that function (group DWS).

Results. It has been demonstrated that the type of light-curing units has a significant impact on the amount of TEGDMA and UDMA released. The amount of UDMA and TEGDMA monomers released from composite fillings differed significantly depending on the source of polymerization applied, as well as the $\mathrm{pH}$ of the solution and sample storage time.

Conclusions. Elution of the monomers from composite material polymerized using halogen lamp was significantly greater as compared to curing with diode lamps.

Key words: light curing units, triethylene glycol dimethacrylate, urethane dimethacrylate, fluorescence spectrometry 


\section{Introduction}

In the oral cavity, chemical compounds from composite dental fillings can be released. Various factors contribute to this process, including a low degree of monomer conversion (DC\%) of the polymer matrix (the reported $\mathrm{DC} \%$ varies between 35 and 77\%), ${ }^{1,2}$ washing out with such fluids as saliva, gingival crevicular fluid, drinks consumed, an adequate light activation technique, the processes of enzymatic degradation of the material, the quality of lightcuring unit used, the regime of restorative procedure, or wearing dental prostheses. The substances released from polymer-based materials demonstrate allergenic, cytotoxic, genotoxic, mutagenic, embryotoxic, teratogenic, and estrogenic properties. ${ }^{3-11}$

More than 35 substances released from composite fillings have been identified. Among these, basic monomers and the so-called co-monomers are most often reported. Substantial cytotoxic potential is observed in the basic monomers, such as bisphenol A-glycidyl methacrylate (Bis-GMA) and urethane dimethacrylate (UDMA), which inhibit cell growth in vitro, at the concentration of $0.1 \mathrm{mM} .^{3}$ Among the comonomers, diethyleneglycol dimethacrylate (DEGDMA) and triethyleneglycol dimethacrylate (TEGDMA) exhibit the worst biocompatibility. It has been demonstrated that monomers also have sensitizing properties. Among the most allergenic ones, there are 2-hydroxyethyl methacrylate (HEMA), ethyleneglycol dimethacrylate (EGDMA) and TEGDMA. Authors describe allergic reactions on the oral mucosal membrane of patients; however, dentists are more prone to contact allergies. ${ }^{3}$ The frequency of occurrence of allergy to metacrylates among dentists and their personnel varies between 1.3 and $14 \% .{ }^{12}$ Often, apart from skin lesions, asthma and sinusitis occur. Latex gloves do not protect against monomers, which penetrate through them within $1 \mathrm{~min} .{ }^{12}$ Some substances released from composite fillings may bind with estrogen receptors, mimicking natural hormones. They are called xeno-estrogens. Among them, there are: bisphenol A (BPA), bisphenol A-glycidyl methacrylate (Bis-GMA), bisphenol A-dimethacrylate (Bis-DMA), and TEGDMA. ${ }^{13}$ Monomers have a damaging effect on cell genetic material; they disturb the regulation of cell growth cycle as well as the oxidation-reduction balance that may activate reactions leading to apoptosis. ${ }^{3,7,14}$

The type of light source used for photopolymerization has a considerable influence on the amount of monomers released from composite resin materials. Light-curing units used in dentistry include conventional quartz-tungstenhalogen (QTH, still in use), light-emitting diode (LED), plasma arc (PAC) lamps, and argon laser. The following parameters differentiate them: the light source and optic elements, the amount of thermal energy emitted, the efficiency of material polymerization and the intensity of curing, the performance efficiency, the existence of voltage stabilization system. ${ }^{15}$
The main feature which distinguishes LED lamps from halogen light-curing units is the source of light. A halogen lamp produces light by heating a metal filament wire to a high temperature until it glows. The spectrum of emitted waves is in the broad range of $360-560 \mathrm{~nm}$, while the luminous intensity peak is in the range of 400-500 $\mathrm{nm}$. Producers install special systems of filters to eliminate the useless radiation of ultraviolet or infrared ranges. Also, the elements of optical system and the bulb itself are subject of gradual degradation. As a result of those processes, the amount of emitted light is insufficient. It is assumed that halogen lamps function with $100 \%$ efficiency for some $50 \mathrm{~h}$, which directly influences the increased presence of residual monomers, that is, their low level of conversion. ${ }^{16}$

In diode lamps, the sources of light emission are semiconductor $\mathrm{p}-\mathrm{n}$ junctions or diodes (precisely light-emitting diodes, LEDs). The semiconductor used there is gallium nitride $(\mathrm{GaN})$. The conduction of that compound is associated with the number of electrons and holes in the valence band of its atoms. The selection of specific semiconductor depends upon the selected range of emitted waves. The average spectra of diode lamps vary from 440 to $495 \mathrm{~nm}$. The efficiency of LED lamps is approx. 10 times higher than that of halogen lamps, as the length of the emitted wave is better adjusted to the photoinitiators used in light-cured materials. ${ }^{17}$ In the majority of composite materials, camphorquinone is the photoinitiator. It is activated by light of a wavelength of $468 \mathrm{~nm}$. Better selectivity of diode lamps contributes to the reduction of the light intensity by $40-70 \%$ in the course of polymerization of dental materials in comparison with halogen lamps. ${ }^{17}$ Due to the narrow radiation spectrum, producers eliminated the need of applying filter systems in those lamps. As a result, they can function with $100 \%$ efficiency for some 10,000 $\mathrm{h} .{ }^{17}$ However, not all dental materials may be cured with diode lamps. The above applies to materials in which the initiators or co-initiators of polymerization react to waves whose lengths are outside the emission range of LEDs.

The aim of the study was to assess the amount of TEGDMA and UDMA monomers released from composite dental filling materials to the solution, depending upon the light-curing units used for polymerization - halogen or diode ones, with and without the soft start function.

\section{Material and methods}

From Filtek Supreme XT composite material (3M ESPE, St. Paul, USA; dentinal shades A3D, A4D, B3D), 4 groups of 10 samples were prepared using standardized molds (the diameter of $15 \pm 1 \mathrm{~mm}$ and the thickness of $0.5 \pm 0.1 \mathrm{~mm}$ ). The samples were polymerized using halogen (Translux LC, Heraeus Kulzer, Hanau, Germany - group H) and diode (Elipar FreeLight 2, 3M ESPE) light-curing units. A diode lamp was used with a soft start function (group DS) and the continuous light mode (group DWS). Soft start 
polymerization means that irradiation is initiated with light of lower intensity and continued with higher irradiation compared to that in the continuous method. In the Elipar FreeLight 2 lamp, the intensity increases exponentially. The curing time was $40 \mathrm{~s}$ for all lamps. The control group consisted of 10 non-polymerized samples (group N). All samples were stored in Eppendorf tubes with $1 \mathrm{~mL}$ of citrate-phosphate buffer (No. P 4809, Perkin Elmer Inc., Waltham, USA) with different $\mathrm{pH}$ levels (4, 6 and 8) for $24 \mathrm{~h}$ and 6 months, at $36.6^{\circ} \mathrm{C} .^{18,19}$ After $24 \mathrm{~h}$ and 6 months, the polymerized and non-polymerized materials were removed from the buffer. The samples examined after $24 \mathrm{~h}$ and 6 months (10 in each group) were separate collections of research material. The quantitative analysis of the residual monomer leached into solutions was carried out using a fluorescent spectrometer LS45 (Perkin Elmer Inc.), with a $0.6 \mathrm{~mL}$ quartz cuvette. The absorbance measurements of the samples were taken in reference to a buffer with corresponding $\mathrm{pH}$. The optimum values of excitation (ex) and emission (em) for model substance (TEGDMA No. 90412 and UDMA No. 436909, Perkin Elmer Inc.) were determined using a spectrophotometer (Shimadzu UV-160A, Kioto, Japan). The values recorded were as follows: for TEGDMA $\lambda_{\mathrm{ex}}=223 \mathrm{~nm}$ and $\lambda_{\mathrm{em}}=290 \mathrm{~nm}$, and for UDMA $\lambda_{\mathrm{ex}}=219 \mathrm{~nm}$ and $\lambda_{\mathrm{em}}=285 \mathrm{~nm}$.

Statistical analysis of the data was performed using STATISTICA software v. 8.0 (StatSoft Inc., Tulsa, USA). Values in all groups were checked for normal distribution, applying the normality of the Shapiro-Wilk and Kolmogorov tests. If the distribution remained normal in both dependency tests, the data was analyzed using tests of 2 or multiple averages. In other cases, the Mann-Whitney U and the Kruskal-Wallis tests were used. If more than 1 sample has demonstrated differences in the tests (multiple averages or Kruskal-Wallis tests), post-hoc tests were performed. Statistical significance was set at $\mathrm{p} \leq 0.05$.

\section{Results}

The mean concentrations of UDMA and TEGDMA monomers released into the citrate-phosphate buffer of different $\mathrm{pH}(4,6,8)$ after $24 \mathrm{~h}$ and 6 months, and a kind of distribution are presented in Tables 1 and 2 . Between $24 \mathrm{~h}$ and 6 months, the mean concentrations of UDMA and TEGDMA significantly increased $(\mathrm{p}<0.001)$ within all the groups, irrespective of the $\mathrm{pH}$ of the buffer (Table 3).

After $24 \mathrm{~h}$, non-polymerized samples $(\mathrm{N})$ released significantly more UDMA than samples polymerized using a diode lamp (DS and DWS) at $\mathrm{pH} 4$ and samples cured using a diode lamp without the soft start function (DWS) in the solutions having $\mathrm{pH} 6$ and 8. The release of UDMA occurred at a significant lower rate in samples cured with a diode lamp (DS and DWS) when compared with samples cured using a halogen lamp $(\mathrm{H})$ in the solutions of $\mathrm{pH} 4$ and 6 . In the buffer $\mathrm{pH} 8$ with the same residence time, there was significantly less $(\mathrm{p}<0.05)$ UDMA when samples were cured with a diode lamp without the soft start function (DWS) compared with the samples polymerized using a halogen lamp $(\mathrm{H})$.

After 6 months, no significant differences were found in the release of UDMA to the buffer $\mathrm{pH} 4$ in all groups. In the buffer $\mathrm{pH} 6$, the release of that monomer occurred to be significantly higher in uncured samples $(\mathrm{N})$. However, when the $\mathrm{pH}$ of the buffer was 8 , a reverse situation was noted - a significantly lower concentration of UDMA in group $\mathrm{N}$ as compared to other groups. In the buffer $\mathrm{pH}$ 8 , a significantly higher release of that monomer was observed in the DWS group than in the N, DS and $\mathrm{H}$ groups ( $p<0.001$ ). In the $\mathrm{H}$ group, the amount of UDMA in the buffer was significantly lower when compared with the DS group ( $\mathrm{p}<0.05)$. The results are shown in Table 4 .

After $24 \mathrm{~h}$, in all groups, the mean concentration of UDMA in the buffer $\mathrm{pH} 4$ was significantly higher than

Table 1. The amount of UDMA $(\mu \mathrm{g} / \mathrm{g}$ ) released from composite material into citrate-phosphate buffer at different pH level after $24 \mathrm{~h}$ and $6 \mathrm{months}$

\begin{tabular}{|c|c|c|c|c|c|c|c|c|c|}
\hline \multirow{3}{*}{$\begin{array}{l}\text { Type of } \\
\text { sample }\end{array}$} & \multirow{3}{*}{$\begin{array}{l}\text { Number } \\
\text { of } \\
\text { measure- } \\
\text { ments }\end{array}$} & \multicolumn{4}{|c|}{$24 \mathrm{~h}(\mathrm{pH} 4 / \mathrm{pH} 6 / \mathrm{pH} 8)$} & \multicolumn{4}{|c|}{6 months (pH 4 / pH $6 / \mathrm{pH} 8)$} \\
\hline & & \multirow{2}{*}{$\begin{array}{l}\text { mean } \\
(\mu \mathrm{g} / \mathrm{g})\end{array}$} & \multirow{2}{*}{$\begin{array}{l}\text { standard } \\
\text { deviation }\end{array}$} & \multicolumn{2}{|c|}{ standard normal distribution } & \multirow{2}{*}{$\begin{array}{l}\text { mean } \\
(\mu \mathrm{g} / \mathrm{g})\end{array}$} & \multirow{2}{*}{$\begin{array}{l}\text { standard } \\
\text { deviation }\end{array}$} & \multicolumn{2}{|c|}{ standard normal distribution } \\
\hline & & & & $\begin{array}{c}\text { Shapiro-Wilk } \\
\text { test }\end{array}$ & $\begin{array}{c}\text { Kolmogorov } \\
\text { test }\end{array}$ & & & $\begin{array}{l}\text { Shapiro-Wilk } \\
\text { test }\end{array}$ & $\begin{array}{c}\text { Kolmogorov } \\
\text { test }\end{array}$ \\
\hline $\mathrm{N}$ & $\begin{array}{c}10 / \\
10 / \\
10\end{array}$ & $\begin{array}{c}94.78 / \\
12.09 / \\
8.65\end{array}$ & $\begin{array}{c}24.81 / \\
4.07 / \\
1.01\end{array}$ & $\begin{array}{l}+1 \\
+/ \\
-\end{array}$ & $\begin{array}{l}+1 \\
+1 \\
+\end{array}$ & $\begin{array}{c}163.37 / \\
161.57 / \\
17.33\end{array}$ & $\begin{array}{c}32.85 / \\
75.31 / \\
3.90\end{array}$ & $\begin{array}{l}+1 \\
+1 \\
+\end{array}$ & $\begin{array}{l}+1 \\
+1 \\
+\end{array}$ \\
\hline DS & $\begin{array}{c}10 / \\
10 / \\
10\end{array}$ & $\begin{array}{c}60.03 / \\
8.94 / \\
7.64\end{array}$ & $\begin{array}{c}9.25 / \\
1.74 / \\
1.15\end{array}$ & $\begin{array}{l}-1 \\
-1 \\
+\end{array}$ & $\begin{array}{l}+/ \\
+/ \\
+\end{array}$ & $\begin{array}{c}364.96 / \\
118.52 / \\
100.33\end{array}$ & $\begin{array}{c}247.65 / \\
38.16 / \\
15.30\end{array}$ & $\begin{array}{l}-1 \\
+1 \\
+\end{array}$ & $\begin{array}{l}+/ \\
+/ \\
+\end{array}$ \\
\hline DBS & $\begin{array}{c}10 / \\
10 / \\
10\end{array}$ & $\begin{array}{c}62.73 / \\
7.83 / \\
7.28\end{array}$ & $\begin{array}{l}8.91 / \\
1.14 / \\
1.26\end{array}$ & $\begin{array}{l}+1 \\
+/ \\
+\end{array}$ & $\begin{array}{l}+1 \\
+1 \\
+\end{array}$ & $\begin{array}{c}349.66 / \\
95.12 / \\
142.92\end{array}$ & $\begin{array}{c}260.23 / \\
38.07 / \\
38.49\end{array}$ & $\begin{array}{l}-1 \\
+1 \\
+\end{array}$ & $\begin{array}{l}-1 \\
+1 \\
+\end{array}$ \\
\hline $\mathrm{H}$ & $\begin{array}{c}10 / \\
10 / \\
10\end{array}$ & $\begin{array}{c}86.78 / \\
12.11 / \\
8.99\end{array}$ & $\begin{array}{c}25.51 / \\
2.32 / \\
1.26\end{array}$ & $\begin{array}{l}-1 \\
+1 \\
+\end{array}$ & $\begin{array}{l}+1 \\
+/ \\
+\end{array}$ & $\begin{array}{c}392.37 / \\
115.00 / \\
81.97\end{array}$ & $\begin{array}{c}333.16 / \\
19.52 / \\
8.28\end{array}$ & $\begin{array}{l}-1 \\
+1 \\
+\end{array}$ & $\begin{array}{l}+1 \\
+1 \\
+\end{array}$ \\
\hline
\end{tabular}

$\mathrm{N}$ - group of samples non-polymerized; DS - group of samples polymerized using diode light-curing unit with soft start function; DBS - group of samples polymerized using diode light-curing unit without soft start function; $\mathrm{H}$ - group of samples polymerized using halogen light-curing unit. 
Table 2. The amount of TEGDMA $(\mu \mathrm{g} / \mathrm{g})$ released from composite material into citrate-phosphate buffer at different $\mathrm{pH}$ level after $24 \mathrm{~h}$ and $6 \mathrm{months}$

\begin{tabular}{|c|c|c|c|c|c|c|c|c|c|}
\hline \multirow{3}{*}{$\begin{array}{l}\text { Type of } \\
\text { sample }\end{array}$} & \multirow{3}{*}{$\begin{array}{l}\text { Number } \\
\text { of } \\
\text { measure- } \\
\text { ments }\end{array}$} & \multicolumn{4}{|c|}{$24 \mathrm{~h}(\mathrm{pH} 4 / \mathrm{pH} 6 / \mathrm{pH} 8)$} & \multicolumn{4}{|c|}{6 months (pH 4 / pH $6 / \mathrm{pH} 8)$} \\
\hline & & \multirow{2}{*}{$\begin{array}{l}\text { mean } \\
{[\mu \mathrm{g} / \mathrm{g}]}\end{array}$} & \multirow{2}{*}{$\begin{array}{l}\text { standard } \\
\text { deviation }\end{array}$} & \multicolumn{2}{|c|}{ standard normal distribution } & \multirow[b]{2}{*}{$\begin{array}{l}\text { mean } \\
{[\mu \mathrm{g} / \mathrm{g}]}\end{array}$} & \multirow{2}{*}{$\begin{array}{l}\text { standard } \\
\text { deviation }\end{array}$} & \multicolumn{2}{|c|}{ standard normal distribution } \\
\hline & & & & $\begin{array}{c}\text { Shapiro-Wilk } \\
\text { test }\end{array}$ & $\begin{array}{c}\text { Kolmogorov } \\
\text { test }\end{array}$ & & & $\begin{array}{c}\text { Shapiro-Wilk } \\
\text { test }\end{array}$ & $\begin{array}{c}\text { Kolmogorov } \\
\text { test }\end{array}$ \\
\hline $\mathrm{N}$ & $\begin{array}{c}10 / \\
10 / \\
10\end{array}$ & $\begin{array}{l}93.25 / \\
81.80 / \\
73.79\end{array}$ & $\begin{array}{c}21.94 / \\
25.63 / \\
11.34\end{array}$ & $\begin{array}{l}+1 \\
+1 \\
-\end{array}$ & $\begin{array}{l}+1 \\
+1 \\
+\end{array}$ & $\begin{array}{c}164.78 / \\
1002.26 / \\
151.77\end{array}$ & $\begin{array}{c}25.37 / \\
450.30 / \\
39.27\end{array}$ & $\begin{array}{l}+1 \\
+1 \\
+\end{array}$ & $\begin{array}{l}+1 \\
+1 \\
+\end{array}$ \\
\hline DS & $\begin{array}{c}10 / \\
10 / \\
10\end{array}$ & $\begin{array}{l}60.62 / \\
57.54 / \\
62.69\end{array}$ & $\begin{array}{c}9.55 / \\
8.48 / \\
6.17\end{array}$ & $\begin{array}{l}+1 \\
+1 \\
+\end{array}$ & $\begin{array}{l}+1 \\
+1 \\
+\end{array}$ & $\begin{array}{c}336.48 / \\
724.74 / \\
868.31\end{array}$ & $\begin{array}{c}244.28 / \\
205.49 / \\
134.20\end{array}$ & $\begin{array}{l}-1 \\
-1 \\
+\end{array}$ & $\begin{array}{l}+1 \\
+1 \\
+\end{array}$ \\
\hline DBS & $\begin{array}{c}10 / \\
10 / \\
10\end{array}$ & $\begin{array}{c}62.16 / \\
49.65 / \\
60.17\end{array}$ & $\begin{array}{l}7.63 / \\
7.33 / \\
9.30\end{array}$ & $\begin{array}{l}+1 \\
+1 \\
+\end{array}$ & $\begin{array}{l}+1 \\
+1 \\
+\end{array}$ & $\begin{array}{l}315.65 / \\
632.66 / \\
1250.57\end{array}$ & $\begin{array}{c}265.82 / \\
217.71 / \\
337.96\end{array}$ & $\begin{array}{l}-1 \\
+1 \\
+\end{array}$ & $\begin{array}{l}-1 \\
+1 \\
+\end{array}$ \\
\hline $\mathrm{H}$ & $\begin{array}{c}10 / \\
10 / \\
10\end{array}$ & $\begin{array}{c}79.84 / \\
73.32 / \\
74.82\end{array}$ & $\begin{array}{c}19.03 / \\
12.89 / \\
7.86\end{array}$ & $\begin{array}{l}+1 \\
+1 \\
+\end{array}$ & $\begin{array}{l}+1 \\
+1 \\
+\end{array}$ & $\begin{array}{l}404.61 / \\
704.31 / \\
712.55\end{array}$ & $\begin{array}{c}393.20 / \\
135.78 / \\
74.55\end{array}$ & $\begin{array}{l}-1 \\
+/ \\
+\end{array}$ & $\begin{array}{l}+1 \\
+/ \\
+\end{array}$ \\
\hline
\end{tabular}

$\mathrm{N}$ - group of samples non-polymerized; DS - group of samples polymerized using diode light-curing unit with soft start function; DBS - group of samples polymerized using diode light-curing unit without soft start function; $\mathrm{H}$ - group of samples polymerized using halogen light-curing unit.

Table 3. UDMA or TEGDMA monomers released from composite material, depending on the sample residence time in citrate-phosphate buffer - pH 4, $\mathrm{pH} 6, \mathrm{pH} 8$

\begin{tabular}{|c|c|c|c|c|}
\hline Type of sample pH 4 / pH $6 /$ pH 8 & $\begin{array}{c}\text { UDMA } \\
24 \mathrm{~h}-6 \text { months } \\
\text { t DA }\end{array}$ & $\begin{array}{c}\text { UDMA } \\
24 \mathrm{~h}-6 \text { months } \\
\text { t UM-W }\end{array}$ & $\begin{array}{c}\text { TEGDMA } \\
24 \mathrm{~h}-6 \text { months } \\
\text { t DA }\end{array}$ & $\begin{array}{c}\text { TEGDMA } \\
24 \mathrm{~h}-6 \text { month } \\
\text { t UM-W }\end{array}$ \\
\hline $\mathrm{N}$ & $\mathrm{a} / \mathrm{a} /-$ & $-1-/ a$ & $\mathrm{a} / \mathrm{a} /-$ & $-1-/ a$ \\
\hline DS & $-/-/ a$ & $\mathrm{a} / \mathrm{a} /-$ & $-/-/ a$ & $\mathrm{a} / \mathrm{a} /-$ \\
\hline DBS & $-/ a / a$ & $\mathrm{a} /-/-$ & $-/ a / a$ & $a /-/-$ \\
\hline $\mathrm{H}$ & $-/ a / a$ & $\mathrm{a} /-/-$ & $-/ a / a$ & $a /-/-$ \\
\hline
\end{tabular}

$\mathrm{N}$ - group of samples non-polymerized; DS - group of samples polymerized using diode light-curing unit with soft start function; DBS - group of samples polymerized using diode light-curing unit without soft start function; $\mathrm{H}$ - group of samples polymerized using halogen light-curing unit; a - $\mathrm{p}<0.001$; t DA - double average test; t UM-W - U Mann-Whitney test.

Table 4. UDMA monomer released from composite material into citrate-phosphate buffer (pH 4, pH 6, pH 8), depending upon polymerization light-curing unit used, after $24 \mathrm{~h}$ and 6 months

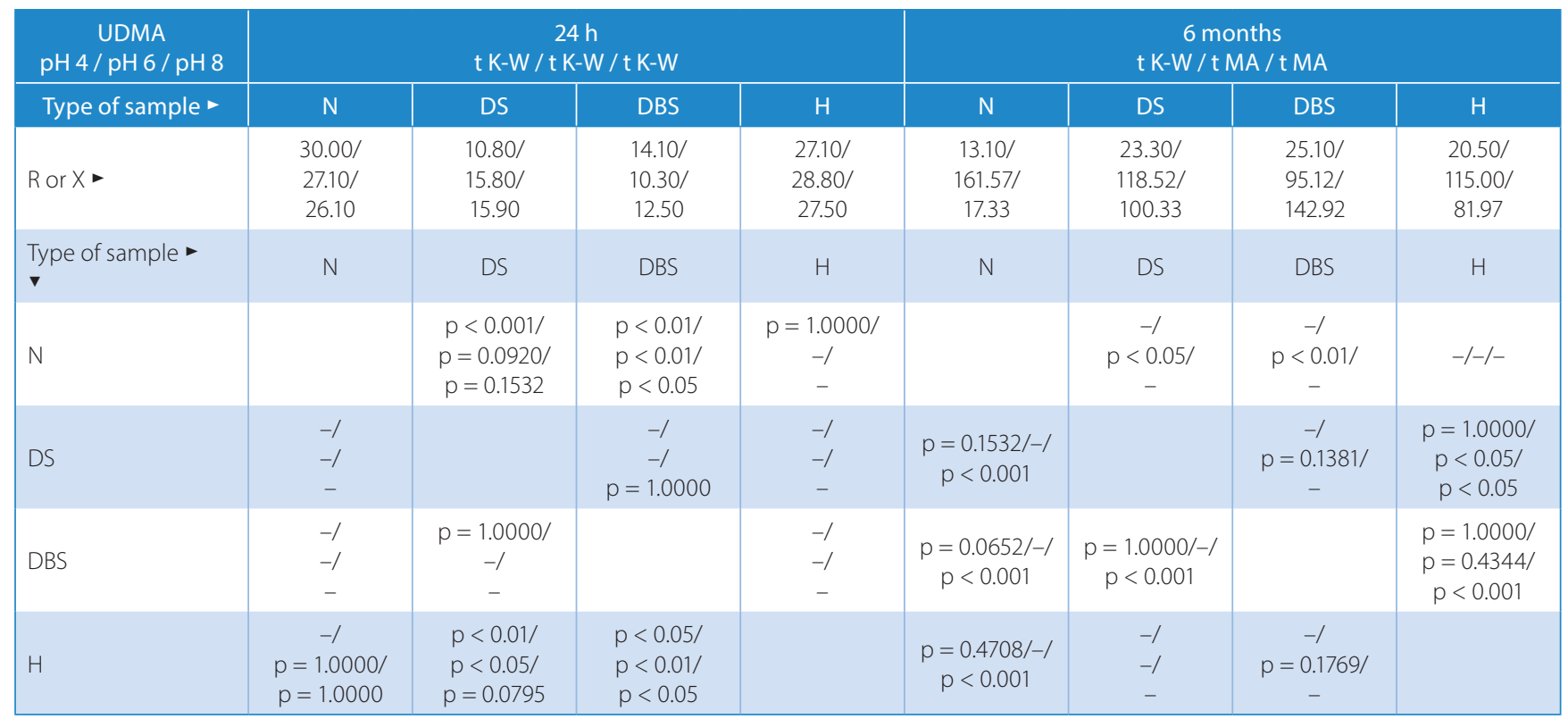

$\mathrm{N}$ - group of samples non-polymerized; DS - group of samples polymerized using diode light-curing unit with soft start function; DBS - group of samples polymerized using diode light-curing unit without soft start function; $\mathrm{H}$ - group of samples polymerized using halogen light-curing unit; $\mathrm{R}$ - average $\mathrm{t}$ MA; $\mathrm{X}$ - average $\mathrm{K}$ K-W; t MA - multiple average test; $\mathrm{K}$-W - Kruskal-Wallis test. 
Table 5. UDMA monomer released into citrate-phosphate buffer, depending on pH, after $24 \mathrm{~h}$ and 6 months

\begin{tabular}{|c|c|c|c|c|c|c|}
\hline \multirow{2}{*}{$\begin{array}{l}\text { UDMA } \\
\text { Sample N / DS / DBS / H } \\
\text { pH value - }\end{array}$} & \multicolumn{3}{|c|}{$\begin{array}{c}24 \mathrm{~h} \\
\mathrm{t} \mathrm{K}-\mathrm{W} / \mathrm{t} \mathrm{K}-\mathrm{W} / \mathrm{t} \mathrm{MA} / \mathrm{t} \mathrm{K}-\mathrm{W}\end{array}$} & \multicolumn{3}{|c|}{$\begin{array}{c}6 \text { months } \\
\text { t MA / t K-W/ t K-W / t K-W }\end{array}$} \\
\hline & 4 & 6 & 8 & 4 & 6 & 8 \\
\hline R or $X-$ & $\begin{array}{l}25.50 / \\
25.50 / \\
62.74 / \\
25.50\end{array}$ & $\begin{array}{l}13.00 / \\
13.20 / \\
7.83 / \\
14.50\end{array}$ & $\begin{array}{l}8.00 / \\
7.80 / \\
7.28 / \\
6.50\end{array}$ & $\begin{array}{c}163.37 / \\
25.30 / \\
24.30 / \\
25.10\end{array}$ & $\begin{array}{c}161.57 / \\
12.30 / \\
7.90 / \\
15.10\end{array}$ & $\begin{array}{c}17.33 / \\
8.90 / \\
14.30 / \\
6.30\end{array}$ \\
\hline $\mathrm{pH}$ value & 4 & 6 & 8 & 4 & 6 & 8 \\
\hline 4 & & $\begin{array}{l}p<0.01 / \\
p<0.01 / \\
p<0.001 / \\
p<0.01\end{array}$ & $\begin{array}{l}p<0.001 / \\
p<0.001 / \\
p<0.001 / \\
p<0.001\end{array}$ & & $\begin{array}{c}p=0.4665 / \\
p<0.01 / \\
p<0.001 / \\
p<0.05\end{array}$ & $\begin{array}{l}p<0.001 / \\
p<0.001 / \\
p<0.05 / \\
p<0.001\end{array}$ \\
\hline 6 & & & $\begin{array}{l}p=0.3061 / \\
p=0.2553 / \\
p=0.4080 / \\
p=0.0632\end{array}$ & & & $\begin{array}{c}p<0.001 / \\
p=0.2553 / \\
\quad-/ \\
p<0.05\end{array}$ \\
\hline 8 & & & & & $\begin{array}{l}-/ \\
-/ \\
0.1561 /\end{array}$ & \\
\hline
\end{tabular}

$\mathrm{N}$ - group of samples non-polymerized; DS - group of samples polymerized using diode light-curing unit with soft start function; DBS - group of samples polymerized using diode light-curing unit without soft start function; $\mathrm{H}$ - group of samples polymerized using halogen light-curing unit; $\mathrm{R}$ - average $\mathrm{I}$ MA; $\mathrm{X}$ - average t K-W; t MA - multiple average test; $\mathrm{K}$-W - Kruskal-Wallis test.

in buffers pH 6 and 8. On the other hand, for non-polymerized samples after 6 months, a significantly lower UDMA was noted when the $\mathrm{pH}$ of the buffer was 8 as compared to the solutions with lower $\mathrm{pH}$ values $(\mathrm{p}<0.01)$ (Table 5).

The release of TEGDMA after $24 \mathrm{~h}$ was significantly higher in the non-polymerized group (N) in the buffer $\mathrm{pH}$ 4. At that time, no significant differences occurred in the release of this monomer from the samples cured using a diode lamp (DS and DWS) for all pH values. Regardless of the $\mathrm{pH}$ of the solution, the release of TEGDMA after 24 h was significantly lower when samples were cured with a diode lamp (DS and DWS) in relation to the samples cured with a halogen lamp $(\mathrm{H})$. After 6 months, no significant differences were disclosed in the amount of TEGDMA released to the buffers $\mathrm{pH} 4$ and 6 for all examined samples. However, when the $\mathrm{pH}$ of the solution was 8 , a significantly lower concentration of this monomer was noted in the case of non-polymerized samples as compared with the polymerized ones, whatever the lamp type was $(\mathrm{p}<0.001)$. Samples polymerized using a diode lamp without the soft start function (DWS) released significantly ( $\mathrm{p}<0.001$ ) more TEGDMA to the buffer in comparison with the remaining samples. The results are shown in Table 6.

After $24 \mathrm{~h}$, the release of TEGDMA from non-polymerized samples $(\mathrm{N})$ to the buffer with $\mathrm{pH} 8$ was significantly $(\mathrm{p}<0.05)$ diminished in comparison with the solution of $\mathrm{pH} 4$.

After 6 months, the mean concentration of TEGDMA released from samples $\mathrm{N}$ was significantly lower in solutions pH 4 and 8 in comparison with those of pH 6 (p $<0.001)$.
The highest amount of TEGDMA was released in the DBS group in solutions of $\mathrm{pH}$. The results are presented in Table 7.

\section{Discussion}

The quantitative and qualitative assessment of residual monomers released from composite fillings to external environment has been a subject of investigations by many authors. ${ }^{1,18-25}$ The willingness to examine thoroughly what happens with the composite filling used, to what degree it is degraded and what influence the chemical compounds released from fillings have upon the human organism compelled the search for ever more accurate analytic methods. For the analysis of released monomers, the authors applied gas and liquid chromatography as well as fluorescence spectrophotometry. An intermediate method for examining the condition of fillings after curing, attesting to the degree of conversion of materials exposed to curing, is Raman or Fourier spectrometry. ${ }^{26-30}$ These methods consist of a comparative analysis of double carbon bonds occurring in polymerized and non-polymerized material.

Polydorou et al. studied the release of Bis-GMA, UDMA and TEGDMA from Filtek Supreme XT restorative composite. ${ }^{1}$ The cured and uncured samples were stored in $75 \%$ ethanol solution for $24 \mathrm{~h}, 7$ days, 28 days, and 12 months. Elipar Highlight (3M ESPE) halogen lamp was used in the study, and the following polymerization time was applied: 0, 20, 40, and 80 s. Liquid chromatography-mass spectrometry was used for quantitative and qualitative analysis. 
Table 6. TEGDMA monomer released from composite material into citrate-phosphate buffer (pH 4, pH 6, pH 8), depending upon polymerization light-curing unit used, after $24 \mathrm{~h}$ and after 6 months

\begin{tabular}{|c|c|c|c|c|c|c|c|c|}
\hline \multirow{2}{*}{$\begin{array}{c}\text { TEGDMA } \\
\mathrm{pH} 4 / \mathrm{pH} / \mathrm{pH} 8 \\
\text { Type of sample }\end{array}$} & \multicolumn{4}{|c|}{$\begin{array}{c}24 \mathrm{~h} \\
\mathrm{t} \mathrm{MA} / \mathrm{t} \mathrm{MA} / \mathrm{t} \mathrm{K}-\mathrm{W}\end{array}$} & \multicolumn{4}{|c|}{$\begin{array}{c}6 \text { months } \\
\mathrm{t} \mathrm{K-W/t} \mathrm{K-W/t} \mathrm{MA}\end{array}$} \\
\hline & $\mathrm{N}$ & DS & DBS & $\mathrm{H}$ & $N$ & DS & DBS & $\mathrm{H}$ \\
\hline Ror $X$ & $\begin{array}{l}93.25 / \\
81.81 / \\
26.30\end{array}$ & $\begin{array}{c}60.62 / \\
57.54 / \\
15.40\end{array}$ & $\begin{array}{c}62.16 / \\
49.65 / \\
11.60\end{array}$ & $\begin{array}{l}79.84 / \\
73.32 / \\
28.70\end{array}$ & $\begin{array}{l}19.20 / \\
27.20 / \\
151.77\end{array}$ & $\begin{array}{l}20.20 / \\
20.10 / \\
868.31\end{array}$ & $\begin{array}{c}20.80 / \\
16.50 / \\
1250.57\end{array}$ & $\begin{array}{l}21.80 / \\
19.20 / \\
712.55\end{array}$ \\
\hline Type of sample & $\mathrm{N}$ & DS & DBS & $\mathrm{H}$ & $\mathrm{N}$ & DS & DBS & $\mathrm{H}$ \\
\hline N & & $\begin{array}{l}p<0.001 / \\
p<0.001 / \\
p=0.1112\end{array}$ & $\begin{array}{l}p<0.001 / \\
p<0.001 / \\
p<0.05\end{array}$ & $\begin{array}{c}p<0.05 / \\
p=0.1129 / \\
-\end{array}$ & & $p=\begin{array}{l}-/ \\
0.5234 /\end{array}$ & $p=\begin{array}{l}-/ \\
0.1221 / \\
-\end{array}$ & $p=0.2555 /$ \\
\hline DS & $\begin{array}{l}-1 \\
-1 \\
-\end{array}$ & & $\begin{array}{c}-/ \\
p=0.1297 / \\
p=1.000\end{array}$ & $\begin{array}{l}-1 \\
-1 \\
-\end{array}$ & $\begin{array}{c}\mathrm{p}=1.0000 / \\
-/ \\
\mathrm{p}<0.001\end{array}$ & & $p=\begin{array}{l}-/ \\
- \\
-\end{array}$ & $\begin{array}{c}-/ \\
p=1.000 / \\
p<0.05\end{array}$ \\
\hline DBS & $\begin{array}{l}-1 \\
-1 \\
-\end{array}$ & $\begin{array}{c}p=0.4146 / \\
-/ \\
-\end{array}$ & & $\begin{array}{l}-1 \\
-1 \\
-\end{array}$ & $\begin{array}{c}p=1.0000 / \\
-/ \\
p<0.001\end{array}$ & $\begin{array}{c}p=1.0000 / \\
-/ \\
p<0.001\end{array}$ & & $\begin{array}{c}-/ \\
-/ \\
p<0.001\end{array}$ \\
\hline $\mathrm{H}$ & $\begin{array}{c}-1 \\
-1 \\
p=1.000\end{array}$ & $\begin{array}{l}p<0.01 / \\
p<0.05 / \\
p<0.05\end{array}$ & $\begin{array}{c}p<0.01 / \\
p<0.001 / \\
p<0.01\end{array}$ & $\begin{array}{l}-1 \\
-1 \\
-\end{array}$ & $\begin{array}{c}p=1.0000 / \\
-/ \\
p<0.001\end{array}$ & $p=1.0000 /$ & $\begin{array}{c}p=1.0000 / \\
-/ \\
-\end{array}$ & \\
\hline
\end{tabular}

$\mathrm{N}$ - group of non-polymerized sample; DS - group of sample polymerized using diode light-curing unit with soft start function; DBS - group of sample polymerized using diode light-curing unit without soft start function; $\mathrm{H}$ - group of sample polymerized using halogen light-curing unit; $\mathrm{R}$ - average $\mathrm{t}$ MA; $\mathrm{X}$ - average $\mathrm{K}$ K-W; t MA - multiple average test; $\mathrm{K}$-W - Kruskal-Wallis test.

Table 7. TEGDMA monomer released into citrate-phosphate buffer, depending on pH, after 24 h and 6 months

\begin{tabular}{|c|c|c|c|c|c|c|}
\hline $\begin{array}{c}\text { TEGDMA } \\
\text { Sample N/DS / DBS / H }\end{array}$ & \multicolumn{3}{|c|}{$\frac{24 \mathrm{~h}}{\mathrm{t} \mathrm{K}-\mathrm{W} / \mathrm{t} \mathrm{MA} / \mathrm{t} \mathrm{MA} / \mathrm{t} \mathrm{MA}}$} & \multicolumn{3}{|c|}{$\begin{array}{c}6 \text { months } \\
\mathrm{t} \mathrm{MA} / \mathrm{t} \mathrm{K}-\mathrm{W} / \mathrm{t} \mathrm{K}-\mathrm{W} / \mathrm{t} \mathrm{K}-\mathrm{W}\end{array}$} \\
\hline $\mathrm{pH}$ value & 4 & 6 & 8 & 4 & 6 & 8 \\
\hline Ror $X$ & $\begin{array}{l}19.50 / \\
60.62 / \\
62.16 / \\
79.34\end{array}$ & $\begin{array}{l}16.00 / \\
57.54 / \\
49.65 / \\
73.32\end{array}$ & $\begin{array}{l}11.00 / \\
62.70 / \\
60.17 / \\
74.82\end{array}$ & $\begin{array}{c}164.78 / \\
6.90 / \\
7.50 / \\
9.20\end{array}$ & $\begin{array}{c}1002.26 / \\
17.30 / \\
13.50 / \\
18.10\end{array}$ & $\begin{array}{c}151.77 / \\
22.30 / \\
25.50 / \\
19.20\end{array}$ \\
\hline pH value & 4 & 6 & 8 & 4 & 6 & 8 \\
\hline 4 & & $\begin{array}{c}p=0.5610 / \\
p=0.2037 / \\
p<0.01 / \\
p=0.1538\end{array}$ & $\begin{array}{c}p<0.05 / \\
-/ \\
p=0.2949 / \\
p=0.2155\end{array}$ & & & $\begin{array}{c}\mathrm{p}=0.4561 / \\
-/ \\
-/ \\
-\end{array}$ \\
\hline 6 & & & $\begin{array}{c}\mathrm{p}=0.3061 / \\
-/ \\
-/ \\
-\end{array}$ & $\begin{array}{c}p<0.001 / \\
p<0.05 / \\
p=0.1913 / \\
p<0.05\end{array}$ & & $\begin{array}{c}\mathrm{p}<0.001 / \\
-/ \\
-/ \\
-\end{array}$ \\
\hline 8 & $\begin{array}{c}-/ \\
p=0.2884 / \\
-/ \\
-\end{array}$ & $\begin{array}{c}-/ \\
p=0.855 / \\
p<0.01 / \\
p=0.4060\end{array}$ & & $\begin{array}{c}\quad-/ \\
p<0.001 / \\
p<0.001 / \\
p<0.05\end{array}$ & $\begin{array}{c}-/ \\
p=0.3061 / \\
p<0.01 / \\
p=1.0000\end{array}$ & \\
\hline
\end{tabular}

$\mathrm{N}$ - group of non-polymerized sample; DS - group of sample polymerized using diode light-curing unit with soft start function; DBS - group of sample polymerized using diode light-curing unit without soft start function; $\mathrm{H}$ - group of sample polymerized using halogen light-curing unit; $\mathrm{R}$ - average $\mathrm{t}$ MA; $\mathrm{X}$ - average $\mathrm{K}$ K-W; t MA - multiple average test; $\mathrm{K}$-W - Kruskal-Wallis test.

The release of monomers got significantly reduced with the extension of curing time. ${ }^{1}$ The results of this study are in agreement with our report on monomers released from polymerized samples (40 s) and non-polymerized ones $(0 \mathrm{~s})$ made of the Filtek Supreme XT material, after $24 \mathrm{~h}$ of residence in citrate-phosphate buffer, whatever the
pH level was, and after 6 months, when the $\mathrm{pH}$ of the buffer amounted to 6 . The release of monomers, in accordance with above-mentioned Polydorou el al., also significantly differed in time. The amounts of free TEGDMA dropped, whereas those of the Bis-GMA monomer remained at a similar level. ${ }^{1}$ This part of their results was different 
from our study. This may be ascribed to a shorter observation time (6 months) as well as sample storage conditions (citratephosphate buffer with different $\mathrm{pH}$ levels: $4,6,8$ ). The results of the release of the 3 monomers were presented by the authors quoted in the form of logarithmic function, which is why they prove difficult to refer to the results of this study.

Örtengren et al. analyzed the influence of the solution $\mathrm{pH}$ value and of time upon the release of monomers from the Z-100 composite material. ${ }^{18}$ The samples were stored in citrate-phosphate buffer with different $\mathrm{pH}$ levels $(4,6,8)$ for $24 \mathrm{~h}$ and for 6 months. For the sake of comparison, 2 methods were applied for the sample analysis: gas chromatography and fluorescence spectrophotometry. The highest levels of organic substances release were noted in the case of methacrylic acid, TEGDMA and camphoroquinone. The authors of this study applied identical conditions for sample storage (citrate-phosphate buffer, with the $\mathrm{pH}$ values of $4,6,8$, sample storage time: $24 \mathrm{~h}$ and 6 months). Örtengren et al., in the case of 24 h storage, obtained the following results concerning TEGDMA eluted to the medium: at the $\mathrm{pH}$ of $4-100 \mu \mathrm{g} / \mathrm{g}$, at the $\mathrm{pH}$ of $8-87 \mu \mathrm{g} / \mathrm{g}$ of sample (by fluorescence spectrophotometry). ${ }^{18}$ After 6 months, the amount of TEGDMA increased significantly at the $\mathrm{pH}$ of $4-230 \mu \mathrm{g} / \mathrm{g}$ and at the $\mathrm{pH}$ of $6-320 \mu \mathrm{g} / \mathrm{g}$ of sample. In the analysis by means of gas chromatography, which, in accordance with the authors quoted, proved to be more accurate after $24 \mathrm{~h}$ and after 6 months of storage, a significantly lower level of TEGDMA has been noted at the $\mathrm{pH}$ of 8 in comparison with other $\mathrm{pH}$ values (4 and 6). Applying the other analytical method, the lowest values of monomer release were obtained at the $\mathrm{pH}$ of 6 after $24 \mathrm{~h}$ and at the $\mathrm{pH}$ of 4 after 6 months of storage. ${ }^{18}$ The authors of this study applied the fluorescence spectrophotometry method and obtained similar results after $24 \mathrm{~h}$ of storage (the best convergence for samples cured using a halogen lamp), but in the case where the $\mathrm{pH}$ of the buffer amounted to 8 , the average concentration of TEGDMA was higher than at the $\mathrm{pH}$ of 4 and 6 . After 6 months of storage, the amount of released TEGDMA was higher than in the results obtained by Örtengren el al., using fluorescence spectrophotometry. One should also add that it increased with increasing $\mathrm{pH}$ of the buffer.

Örtengren el al. analyzed water adsorption and solubility of the samples, made of 6 composite materials, in aqueous solution. The analysis of monomers was carried out with liquid chromatography. The sample storage time amounted to 4, 24h as well as 7, 60 and 180 days. They showed that composite materials containing hydrophilic monomers demonstrate higher sorption of water. The composite mass increased via chemical reaction between the filling and water. The monomer released in biggest quantities was TEGDMA, with the highest concentration after 7 days. ${ }^{23}$

Using the gas chromatography method, Moharamzadeh et al. analyzed the influence of various extraction solutions upon the release of TEGDMA, UDMA and Bis-GMA. ${ }^{20}$ The extraction solutions used were: distilled water, isotonic salt solution, artificial saliva as well as Dulbecco medium, without serum and with $10 \%$ fetal calf serum. The results were indicative of a significant influence of the solution in which cured composite samples were stored on the release of monomers. The highest concentration of TEGDMA monomer was noted in the Dulbecco medium with serum. In other solutions, the concentration of this monomer was similar. The release of UDMA and Bis-GMA to the studied solutions was not observed. On the basis of results, the authors found that TEGDMA is leached in high quantities to aqueous solutions.

Sideridou and Achilias analyzed, by means of liquid chromatography, the influence of sample curing time and their storage time upon the release of Bis-GMA, ethoxylated bisphenol A glycol dimethacrylate (Bis-EMA), UDMA, and TEGDMA. ${ }^{24}$ The samples were stored in $75 \%$ ethanol, at $37^{\circ} \mathrm{C}$, for $3,6,24 \mathrm{~h}$, and 3,6 or 30 days. The curing time amounted to 60,80 and $100 \mathrm{~s}$. The authors found an increase of Bis-GMA monomer up to 3 days. After that time, the release was maintained at a stable level. The amount of Bis-EMA monomer released was much higher than that of Bis-GMA monomer throughout the study period (up to 30 days). On the other hand, the release of TEGDMA and UDMA monomers was at a similar level, and much lower in comparison with the above-mentioned monomers. The authors found that the amount of eluted monomers depends upon the chemical structure of the examined compound and sample storage time. ${ }^{24}$

Carvalho et al. investigated the effect of light sources (LED and QTH curing units) and curing mode techniques on sorption, solubility and biaxial flexural strength of a composite resin. ${ }^{31}$ In their opinion, tested curing units produced no influence on sorption, solubility or biaxial flexural strength of tested composite resins. They observed that ethanol storage media caused more damage on a composite resin than water storage media. ${ }^{31}$

Summarizing the above results, it should be stressed that the proper installation and polymerization of the composite material with a diode curing unit reduces the monomer concentration and its negative influence on the dental pulp, surrounding tissues as well as entire organism.

\section{Conclusions}

The amount of UDMA and TEGDMA monomers released from composite fillings differed significantly, depending on the source of polymerization applied as well as the $\mathrm{pH}$ of the solution and sample storage time. The degree of material polymerization depends on the lamp used; significantly more monomers are released from samples polymerized with halogen lamps in comparison with those cured using a diode lamp.

The use of soft start function in a diode lamp did not influence significantly the amount of monomers released from composite samples. 


\section{References}

1. Polydorou O, König A, Hellwig E. Kümmerer K. Long-term release of monomers from modern dental-composite materials. Eur J Oral Sci. 2009;117:68-75.

2. Uctasli S, Tezvergil A, Lassila LVJ, Vallittu PK. The degree of conversion of fiber-reinforced composites polymerized using different light-curing sources. Dent Mater. 2005;21:469-475.

3. Rogalewicz R, Voelkel A.Compounds released from resin-based fillings and their influence on the human body. Dent Forum. 2006;34(1):49-55.

4. Schwengberg $\mathrm{S}$, Bohlen $\mathrm{H}$, Kleinsasser $\mathrm{N}$, et al. In vitro embryotoxicity assessment with dental restorative materials. J Dent. 2005;33:49-55.

5. Kleinsasser NH, Schmid K, Sassen AW, et al. Cytotoxic and genotoxic effects of resin monomers in human salivary gland tissue and lymphocytes as assessed by the single cell microgel electrophoresis (Comet) assay. Biomaterials. 2006:27:1762-1770.

6. Nocca G, Martorana GE, De Sole P, et al. Effects of 1,4-butanediol dimethacrylate and urethane dimethacrylate on $\mathrm{HL}-60$ cell metabolism. Eur J Oral Sci. 2009;117:175-181.

7. Schweikl H, Spagnuolo G, Schmalz G. Genetic and cellular toxicology of dental resin monomers. J Dent Res. 2006;85(10):870-877.

8. Demirci M, Hiller KA, Bosl C, Galler K, Schmalz G, Schweikl H. The induction of oxidative stress, cytotoxicity and genotoxicity by dental adhesives. Dent Mater. 2008;24:362-371.

9. Huang FM, Tsai CH, Ding SJ, Chang YC. Induction of cyclooxygenase-2 expression in human pulp cells stimulated by dentin bonding agents. Oral Surg Oral Med Oral Pathol Oral Radiol Endo. 2005;100: 501-506.

10. Moharamzadeh K, Van Noort R, Brook IM, Scutt AM. Cytotoxicity of resin monomers on human gingival fibroblasts and $\mathrm{HaCaT}$ keratinocytes. Dent Mater. 2007;23:40-44.

11. Lefeuvre M, Bourd K, Loriot MA, et al. TEGDMA modulates glutathione transferase P1 activity in gingival fibroblasts. J Dent Res. 2004; 83(12):914-919.

12. Hamann CP, Rodgers PA, Sullivan KM. Occupational allergens in dentistry. Curr Opin Allergy Clin Immunol. 2004;4:403-409.

13. Mousavinasab SM. Biocompatibility of composite resins. Dent Res J. 2011;8:21-29.

14. Volk J, Engelmann J, Leyhausen G, Geurtsen W. Effects of three resin monomers on the cellular glutathione concetration of cutured human gingival fibroblasts. Dent Mater. 2006;22:499-505.

15. Voltarelli RF, Santos-Daroz CB, Alves MC, Deris AR, Marchi MG. Effect of different light-curing devices and aging procedures on composite Knoop microhardness. Braz Oral Res. 2009;23(4):473-479.

16. Mills RW, Jandt KD, Ashworth SH. Dental composite depth of cure with halogen and blue light emitting diode technology. Br Dent J. 1999:186(8):388-391.

17. Jandt KD, Mills RW, Blackwell GB, Ashworth SH. Depth of cure and compressive strength of dental composites cured with blue light emitting diodes (LEDs). Dent Mater. 2000;16:41-47.
18. Örtengren $\mathrm{U}$, Langer S, Göransson A, Lundgren T. Influence of $\mathrm{pH}$ and time on organic substance release from a model dental composite: A fluorescence spectrophotometry and gas chromatography/mass spectrometry analysis. Eur J Oral Sci. 2004;112:530-537.

19. Örtengren U, Andersson F, Elgh U, Terselius B, Karlsson S. Influence of $\mathrm{pH}$ and storage time on the sorption and solubility behaviour of three composite resin materials. J Dent. 2001;29:35-41.

20. Moharamzadeh K, Van Noort R, Brook IM, Scutt AM. HPLC analysis of components released from dental composites with different resin compositions using different extraction media. J Mater Sci Mater Med. 2007;18:133-137.

21. Munksgaard EC, Peutzfeldt A, Asmussen E. Elution of TEGDMA and BisGMA from a resin and a resin composite cured with halogen or plasma light. Eur J Oral Sci. 2000;108:341-345.

22. Michelsen VB, Moe G, Strøm MB, Jensen E, Lygre H. Quantitative analysis of TEGDMA and HEMA eluted by use of GC/MS and tailor-made internal standards. Dent Mater. 2008;24:724-731.

23. Örtengren $\mathrm{U}$, Wellendorf $\mathrm{H}$, Karlsson S, Ruyter IE. Water sorption and solubility of dental composites and identification of monomers released in an aqueous environment. J Oral Rehabil. 2001;28:11061115.

24. Sideridou ID, Achilias DS. Elution study of unreacted Bis-GMA, TEGDMA, UDMA and Bis-EMA from light-cured dental resin composites using HPLC. J Biomed Mater Res B Appl Biomater. 2005;74(1):617-626.

25. Pulgar R, Olea-Serrano MF, Novillo-Fertrell A, et al. Determination of bishenol $A$ and related aromatic compounds release from Bis-GMA based composites and sealants by high performance liquid chromatography. Environ Health Perspect. 2000;108:21-27.

26. Lee JK, Choi JY, Lim BS, Lee YK, Sakaguchi RL. Change of properties during storage of a UDMA/TEGDMA dental resin. J Biomed Mater Res B Appl Biomater. 2004;68B:216-221.

27. Arrais CAG, Pontes FM, Santos LPS, Leite ER, Giannini M. Degree of conversion of adhesive systems light-cured by LED and halogen light. Braz Dent J. 2007;18(1):54-59.

28. Witzel MF, Calheiros FC, Gonçalves F, Kawano Y, Braga RR. Influence of photoactivation method on conversion, mechanical properties, degradation in ethanol and contraction stress of resin-based materials. J Dent. 2005;33:773-779.

29. Lohbauer U, Rahiotis C, Krämer N, Petschelt A, Eliades G. The effect of different light-curing units on fatigue behavior and degree of conversion of a resin composite. Dent Mater. 2005;21:608-615.

30. Silva EM, Poskus LT, Guimarăes JGA, Lima Barcellos A, Fellows CE. Influence of light polymerization modes on degree of conversion and crosslink density of dental composites. J Mater Sci Mater Med. 2008;19:1027-1032.

31. Carvalho AA, Moreira FCL, Fonseca RB, et al. Effect of light sources and curing mode techniques on sorption, solubility and biaxial flexural strength of a composite resin. J Appl Oral Sci. 2012;20(2):246-252. 